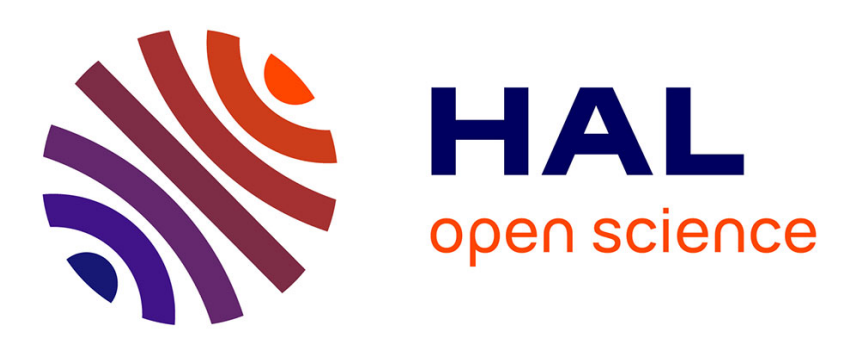

\title{
Demonstration of substances of innate immunity in the integument of the Malayan pangolin ()
}

Wilfried Meyer, Maleewan Liumsiricharoen, Isabelle Hornickel, Apinun

Suprasert, Anke Schnapper, Lutz-Günther Fleischer

\section{- To cite this version:}

Wilfried Meyer, Maleewan Liumsiricharoen, Isabelle Hornickel, Apinun Suprasert, Anke Schnapper, et al.. Demonstration of substances of innate immunity in the integument of the Malayan pangolin (). European Journal of Wildlife Research, 2009, 56 (3), pp.287-296. 10.1007/s10344-009-0318-8 . hal-00535250

\author{
HAL Id: hal-00535250 \\ https://hal.science/hal-00535250
}

Submitted on 11 Nov 2010

HAL is a multi-disciplinary open access archive for the deposit and dissemination of scientific research documents, whether they are published or not. The documents may come from teaching and research institutions in France or abroad, or from public or private research centers.
L'archive ouverte pluridisciplinaire $\mathbf{H A L}$, est destinée au dépôt et à la diffusion de documents scientifiques de niveau recherche, publiés ou non, émanant des établissements d'enseignement et de recherche français ou étrangers, des laboratoires publics ou privés. 


\title{
Demonstration of substances of innate immunity in the integument of the Malayan pangolin (Manis javanica)
}

\author{
Wilfried Meyer • Maleewan Liumsiricharoen • \\ Isabelle Hornickel • Apinun Suprasert • \\ Anke Schnapper • Lutz-Günther Fleischer
}

Received: 22 June 2009 /Revised: 17 August 2009 / Accepted: 19 August 2009 / Published online: 2 September 2009

(C) Springer-Verlag 2009

\begin{abstract}
Using immunohistochemistry, the study demonstrates substances of the innate immunity in the skin of the Malayan pangolin (Manis javanica), referring mainly to the epidermis. The results obtained showed clear reaction differences between the dorsolateral body region with its strong cover of hard horny scales and the abdominal body part with a thick soft stratum corneum and a dense cover of fine hairs. Regarding pathogen recognition receptors, positive reactions for Toll-like receptors were generally weak for TLR2, in contrast to TLR4, that exhibited strong reactions in the epidermis of both body regions, with increasing staining intensities towards the stratum corneum; B-glucan receptors showed positive reactions only for Lficolin and mannose-binding lectin, but not for dectin-1, and only at the abdomen. A generally positive staining for both body regions was obtained for all cationic antimicrobial peptides tested, whereby cathelicidin exhibited strong reaction intensities in all epidermal layers, $\beta$-defensin 2
\end{abstract}

Communicated by W. Lutz

W. Meyer $(\bowtie) \cdot$ I. Hornickel $\cdot$ A. Schnapper

Institute for Anatomy,

University of Veterinary Medicine Foundation,

Bischofsholer Damm 15,

30173 Hannover, Germany

e-mail: wilfried.meyer@tiho-hannover.de

M. Liumsiricharoen $\cdot$ A. Suprasert

Department of Anatomy, Faculty of Veterinary Medicine,

Kasetsart University,

Bangkok, Thailand

\section{L.-G. Fleischer}

Institute of Food Technology and Center of Biotechnology,

Technical University Berlin,

Amrumer Stratum 32,

13353 Berlin, Germany staining was often limited to the stratum basale and the stratum spinosum, and positive reactions for $\beta$-defensin 3 appeared distinctly only in the epidermis of the abdomen; for these peptides, positive reaction staining could also be found in the outer epithelial root sheath of hair follicles, their glandular annexes, and free cells of the dermis. Lysozyme was found in the vital epidermis of both body regions studied, with strong staining limited to the dorsum; strong reactions were also visible in the hair follicles.

Keywords Innate immunity · Epidermis · Pangolin skin

\section{Introduction}

Microbial colonization, proliferation, and invasion are a constant challenge in mammalian skin biology under terrestrial conditions and in the aquatic medium. Thus, the immune system had to develop a special integumental subsystem, and the mammalian skin can be regarded as a tertiary immune organ. Earlier studies on the skin of different wild and domesticated mammals have indicated that antimicrobial functions can be exerted on the skin surface with its mainly commensal microorganisms by, first of all, secretions of the integumental glands (apocrine tubular glands, sebaceous glands). These glands are generally present in the common integument of mediumsized and large mammals as a normal constituent of the hair follicle complex. Additionally, substances are produced by all multilayered epithelia of the skin, such as the epidermis or the outer epithelial root sheath of hair follicles. This defense strategy of the integument primarily depends on the use of several important components of the innate immune system: the pathogen recognition receptors (PRRs), which are able to identify certain characteristical pathogen 
components, the so-called pathogen-associated molecular patterns (PAMPs). Important groups of PRRs are Toll-like receptors and B-glucan receptors (C-type lectin receptors). On the effector side of innate immunity, the more or less directly attacking cationic antimicrobial peptides (CAPs) and proteins like lysozyme are involved, which can be supported by effects of free sugars. Most of the substances in question can be transported onto the epidermal surface for effective extracorporal use (e.g., Meyer et al. 2000, 2001, 2003, 2008; Meyer and Seegers 2004; Meyer 2007; Yasui et al. 2007; Hornickel 2009). The keratinocyte, in particular, is major source for the different innate immunityrelated humoral compounds, including also complement factors, and complement regulatory proteins (e.g., Schroeder 1999; Bos et al. 2001; Debenedictis et al. 2001; Harder et al. 2001; Yang et al. 2001).

Information on the innate immunity of the integument of wild mammals is very rare until now (Meyer et al. 2003, 2008; Meyer and Seegers 2004; Meyer 2007; Yasui et al. 2007). In this context, especially rather small groups like the order Pholidota with the only family Manidae are concerned, whereby this family consists of one genus (Manis) with eight species, and has a special biology (e.g., Mohr 1961; Wilson and Reeder 2005). In the latter case, not only specific aspects like skin defense, but even the basic skin structure is more or less unknown, except for one publication on the nature of the horny scales of this animal, which seem to be a unique integumental feature in mammals, indicating close relations to reptiles (Spearman 1967). The latter view is confirmed by the fact that the hard scales are formed by $\alpha$-keratins and $\beta$-keratins (Tong et al. 1995), which guarantees a high abrasive wear resistance (Tong et al. 2007). Realizing this background, our study was aimed to give introductory detailed information on the construction of the integumental layers, in particular the epidermis, followed by information about the defense mechanisms present as related to the specific skin scale system of pangolins.

Unfortunately, pangolins are strongly threatened by the fact that they are hunted and eaten in many parts of Africa and Asia (mainly China), because their meat is considered to be a delicacy and, more dangerous for the animals, to have certain positive health effects. The latter idea, however, is pure superstition from the biological point of view. So pangolin populations have clearly suffered from illegal trafficking, although countries like Thailand have been active for many years to rescue and protect this very interesting rare mammalian group. Thus, it is a strong additional intention of our work to help to protect the pangolins by shedding some light on their interesting biology by showing some features of their unique skin construction (for the typical anatomy of the Malayan pangolin see Liumsiricharoen et al. 2006).

\section{Materials and methods}

Skin samples from the dorsolateral and the abdominal regions of fresh carcasses of five adult (two males, three females) and two subadult (sex not determined) animals could be used for this study, that was conducted with permission of the Thai government. The animals had been confiscated as smuggled goods by officers at the Khao Pratubchang Wildlife Breeding Center, Ratchaburi province, Thailand. The material was fixed in $10 \%$ neutral buffered formalin for at least $48 \mathrm{~h}$ at room temperature. After fixation, the samples were dehydrated in a graded series of ethanol and embedded via xylene in paraffin wax (Paraplast plus, Tyco Health Care).

For our purposes, $8-\mu \mathrm{m}$ paraffin sections were deparaffinized in Histoclear (Life Science Int.) and carefully hydrated through descending concentrations of ethanol. Afterwards, these sections were routinely stained with hematoxylin-eosin (HE, hemalaun after Delafield) for general light microscopical structure analysis and immunohistochemically, for the determination of the different substances of innate immunity: Toll-like receptor 2 (dilution 1:10; antihuman, from mouse, monoclonal; Biologo), Toll-like receptor 4 (dilution 1:150; antihuman, from mouse, monoclonal; Biologo), dectin-1 (dilution 1:50; antimouse, from goat, polyclonal; Biologo), L-ficolin (dilutions 1:20, 1:50; antihuman, from mouse; Biologo), mannose-binding lectin (MBL; dilutions 1:20, 1:50; antihuman, from mouse, monoclonal; Biologo), ß-defensin 2 (dilution 1:350; antihuman and antimouse, from rabbit, ployclonal; Biologo), B-defensin 3 (dilution 1:1200; antihuman and antimouse, from rabbit, polyclonal; Biologo), cathelicidin (hCAP18; dilution 1:30; antihuman, from mouse, monoclonal; HyCult Biotech.), and lysozyme (dilution 1:50; antihuman, from rabbit, polyclonal; Biologo). Following incubation over night at $4^{\circ} \mathrm{C}$, the reaction was detected by the EnVision ${ }^{\circledR}$ system (Dako), using peroxidase-based very sensitive dextran-polymer visualization. One part of the sections was also digested for 30$60 \mathrm{~min}$ with $0.1 \%$ trypsin (from porcine pancreas, type II, crude; Sigma; Hautzer et al. 1980) or incubated for $30 \mathrm{~min}$ in $\mathrm{TEC}=$ Tris-EDTA-Citrate buffer at $90^{\circ} \mathrm{C}$ prior to the reaction. Control sections were incubated without the antibody and/or the visualization system.

In view of the fact that control of antibody specifity is not practicable without many problems for wild animals, we refer to molecular genetic publications that have demonstrated great structural and functional similarities of the receptors and substances of innate immunity, when the vertebrate groups and particularly, important mammalian orders (Primates, Rodentia, Carnivora, Artiodactyla, Perissodactyla) are concerned. This is true, primarily, of the Toll-like receptor family as a phylogenetically conserved 
mediator of innate immunity essential for microbial recognition (Medzhitov and Janeway 1997; Kaisho and Akira 2003) and the group of the B-glucan receptors, like the ficolins (Kakinuma et al. 2003; Fujita et al. 2004), MBL (Fujita et al. 2004; Takahashi et al. 2006), or Dectin-1 with its collaborative properties (Dennehy and Brown 2007; Taylor et al. 2007). Moreover, the important group of CAPs is concerned, like $B$-defensins, which attack Gram-negative bacteria (Bals et al. 1999; García et al. 2001), or cathelidicin, attacking Gram-negative and Gram-positive bacteria present on many epithelial surfaces and specific for vertebrates (Zanetti 2005; Zhu and Gao 2009). Last but not least, the antimicrobial enzyme lysozyme has to be mentioned, also expressed in all vertebrate groups (Short et al. 1996; Shimada et al. 2008). All this means that the antibodies produced in the goat or the mouse to a certain extent can not only be used for human material but also for members of the other mammalian groups.

The microscopic results were documented with a Zeiss Axioskop equipped with a digital camera (Olympus DP70); the software Olympus DP-SOFT (version 3.1 and 3.2) was applied for picture analysis.

\section{Results}

\section{Basic histological structure}

The integument of the Malayan pangolin (Manis javanica) was dominated by hard and corrugated scales in the dorsolateral body region (Fig. 1a), whereas the ventral body region showed a very dense coat of fine hairs (Fig. 1b). This feature was corroborated by the histological analysis showing an epidermis with a total thickness of 140 to $160 \mu \mathrm{m}$ and a regular system of ridges/papillae, which at the dorsolateral body region consisted of a distinct stratum basale with high columnar cells, two or three layers of the stratum spinosum, and one continuous layer of the stratum granulosum (Fig. 2a). The thickness of the vital epidermis was about $50 \mu \mathrm{m}$. The following inner part of the stratum corneum appeared very conspicuous because it stained very strongly with eosin, indicating high protein amounts (probably prekeratins with many thiol groups), and had a thickness of about $40 \mu \mathrm{m}$. The outer part of the stratum corneum represented the hard scale (thickness 70 to $80 \mu \mathrm{m}$ ) and could not be stained with HE, indicating high amounts of disulphide groups. The epidermis of the abdomen exhibited a clearly different structure with an irregular system of ridges/ papillae (Fig. $2 b$ ), i.e., the stratum basale showed more or less roundish cells, six to eight layers of equally roundish stratum spinosum cells, and a striking stratum granulosum (thickness about $20 \mu \mathrm{m}$ ), because it contained high amounts of large basophilic keratohyalin granules strongly stainable with
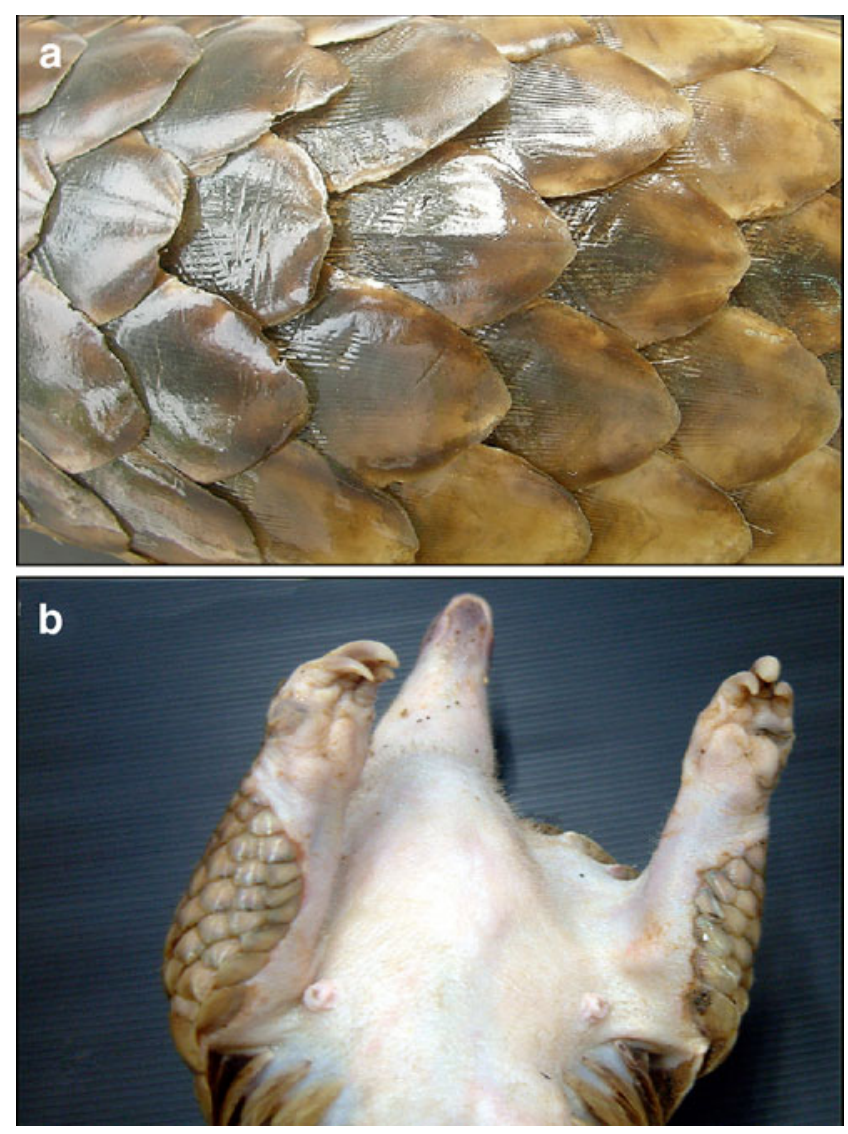

Fig. 1 View of a the dorsolateral body region, with its armor of hard horny scales, and $\mathbf{b}$ the abdominal body region, with a dense coat of fine hairs, of the Malayan pangolin (M. javanica)

hematoxylin. The thick (about $80 \mu \mathrm{m}$ ) stratum corneum consisted of 30 to 40 thin layers homogeneously stained with eosin, indicating a smooth character.

The dermis contained a dense net of collagen fiber bundles, elastic fibers could not be identified, and hair follicles with their typical glandular adnexes, such as apocrine tubular glands and sebaceous glands, that were especially numerous in the abdomen.

\section{Demonstration of Toll-like receptors}

The positive reactions for this group of PRRs varied according to the type studied. TLR2 was weakly discernable in the epidermis, whereby it could be found in the dorsal body region limited to the inner part of the stratum corneum (Fig. 3a), and appeared generally rather inconspicuous in the vital epidermis of the abdominal body part (Fig. 3b). In contrast, TLR4 exhibited strong reactions in the epidermis of both body regions, with a decrease of staining intensities towards the stratum corneum (Fig. 3c). In this connection, the vital epidermis of the dorsum showed a rather homogeneous tinge, whereas in the 
Fig. 2 Basic histological structure of the epidermis of the Malayan pangolin a of the dorsolateral body region showing the different epidermal layers with a remarkable scale system based on two specific corneal layers and $\mathbf{b}$ the abdominal body region with a thick and soft stratum corneum; HE staining. $S B$ stratum basale, $S S$ stratum spinosum, $S G$ stratum granulosum, $S C$ stratum corneum, iSC inner stratum corneum, $o S C$ outer stratum corneum
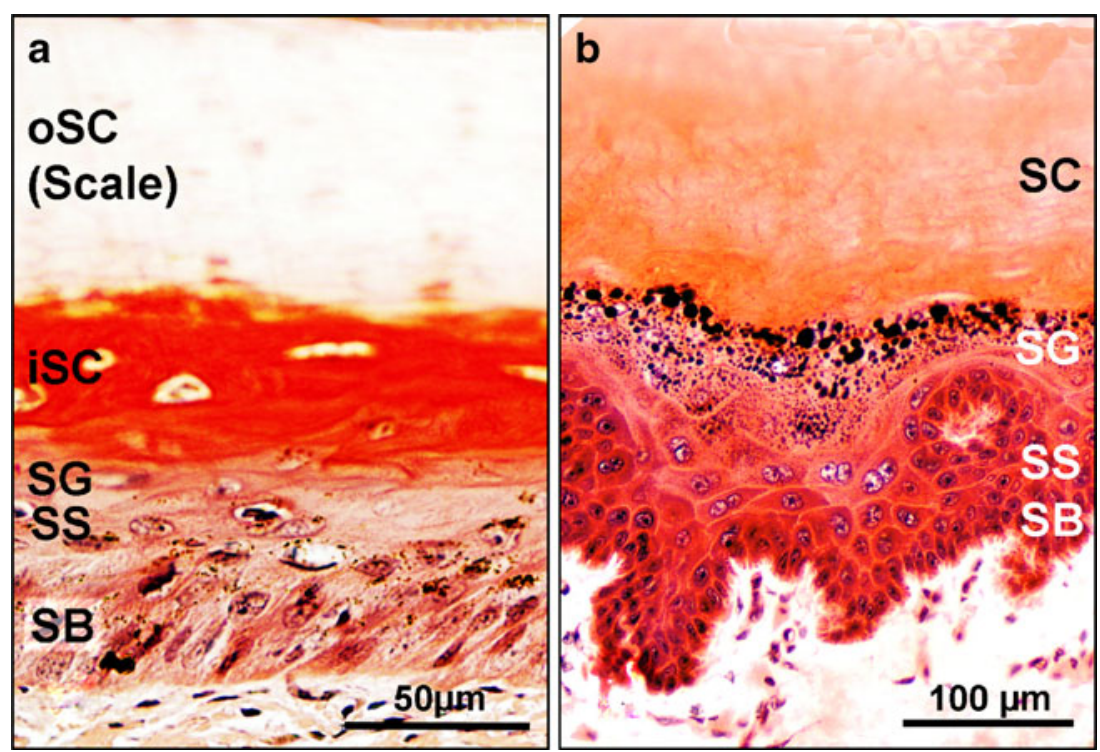

abdomen, the staining concentrated in the stratum basale and diminished in intensity towards the upper layers. (Fig. 3d).

\section{Demonstration of $\beta$-glucan receptors}

The $\beta$-glucan receptors as the second PRR group tested showed positive reactions only for L-ficolin and MBL and only in the abdominal body region. In the dorsal body region, the reactivity for these two C-type lectin receptors (CLRs) was generally negative (results not shown). Both substances concentrated in the lower part of the thick and smooth stratum corneum and reacted generally weakly in the vital epidermis and the outer part of the corneal layer (Fig. 4).Dectin-1 could not be demonstrated, even after the use of the two antigen retrieval methods described.

\section{Demonstration of cationic antimicrobial peptides}

Regarding this more or less ubiquitous group of antimicrobial substances produced in many epithelia of the body, positive staining reactions were obtained for all group members studied. However, ß-defensin 2 staining was restricted to the dorsal body region. Here, it was often limited to the stratum basale and the stratum spinosum (Fig. 5a) and rarely could be found in the upper epidermal layers. Positive reaction staining for $\beta$-defensin 3 appeared in all vital epidermal layers only at the dorsal body region, but seemed rather limited to the upper stratum spinosum or the stratum granulosum in the epidermis of the ventral body part (Fig. 5b, c). Only cathelicidin exhibited always strong reactions in the vital epidermis of both body regions and additionally, in the entire stratum corneum of the abdominal body region
(Fig. 6a, b). In some cases, positive staining for this peptide was visible at the surface of the latter epidermal layer.

For all types of antimicrobial peptides studied, positive reaction staining could be found in the outer epithelial root sheath of the hair follicles, their glandular annexes, and free cells (probably neutrophils) of the dermis.

\section{Demonstration of lysozyme}

Lysozyme was found in the vital epidermis of both body regions studied, however, strong staining intensities were limited to the dorsum, where all epidermal layers generally reacted very distinctly (Fig. 6c), whereas in the epidermis of the abdomen positive but rather weak reactions concentrated in the stratum basale and the lower stratum spinosum (not shown). As observed for the antimicrobial peptides, strong reactions were also visible in the hair follicle epithelia (Fig. 6d) and the glands.

\section{Discussion}

The commensal microbial skin surface flora of terrestrial vertebrates consists of a basic genus and species spectrum (e.g., bacteria: Pseudomonas spp., Acinetobacter spp., Aerosoma spp., Micrococcus spp., Staphylococcus spp., or fungi: Trichophyton spp., Malazessia spp., Candida spp.), although it is continuously influenced by environmental changes (Kloos et al. 1976; Krogh and Christensen 1977; Meyer et al. 2001). In this context, our study clearly demonstrated that antimicrobial defense is a basic feature also of the integument of the pangolin, whereby distinct regional differences comparing the dorsolateral body region 
Fig. 3 Immunohistochemical demonstration of the Toll-like receptor group in the epidermis of the Malayan pangolin; TLR2 in $\mathbf{a}$ the dorsolateral and $\mathbf{b}$ the ventral body region, TLR4 in $\mathbf{c}$ the dorsolateral and $\mathbf{d}$ the ventral body region; diaminobenzidine (DAB) visualization, for abbreviations see Fig. 2
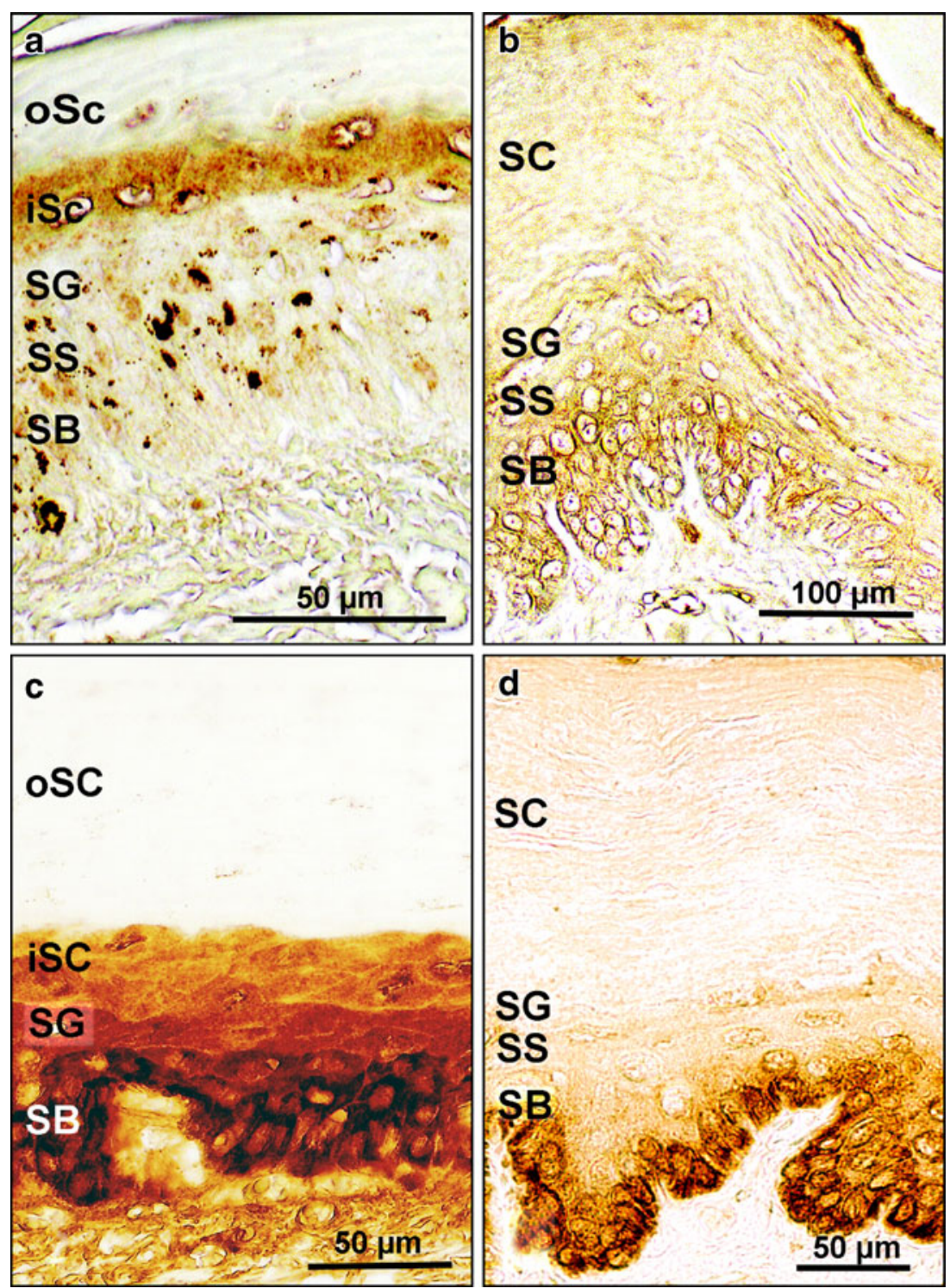

(with a very hard scaly armor) with the abdominal body region (without scales, but with a thick soft stratum corneum and a dense fine hair coat) could be shown. Such differences may generally emphasize that the polished surface of the hard scales (Tong et al. 2007) has no positive habitat qualities for microorganisms, in contrast to the surface of the epidermis of the abdomen with its thick soft and smooth stratum corneum, which is additionally protected by a dense and fine hair coat.

After the use of immunohistochemical technique, we were able to illustrate the presence of all important substances of innate immunity that are also known from other epithelia and organs: Firstly, so-called "sentinel cells" (dendritic cells) and epithelial cells (keratinocytes, epithelial cells of different organ systems, such as the intestinal tract), which express receptors on their surface, that can bind PAMPs on bacteria and fungi. These receptors are called PRRs with the important subgroups of TLRs and $B-$ glucan receptors (CLRs). Regarding Toll-like receptors, TLR2 was found in blood monocytes, lymph nodes, the lung, liver, spleen, bladder, pancreas, small intestine, heart tissue, or skin of the dog (Ishii et al. 2006; Linde et al. 2007). TLR4 was detected in epithelia of the lung and the small intestine, also in the cornea and renal tubules (Wassef et al. 2004). In this context, the fact that not TLR2 but TLR4 became distinctly evident in the pangolin epidermis probably emphasizes that the latter receptor type may not only be expressed by sentinel cells or in intestinal epithelia but equally by keratinizing epithelia. It specifically initiates the innate immune response to common Gram-negative bacteria, which are also active on the skin surface (e.g., Pseudomonas spp., Acetinobacter spp.). TLR4 activation 
Fig. 4 Immunohistochemical demonstration of the $\beta$-glucan receptor group in the epidermis of the Malayan pangolin; Lficolin in a the dorsolateral and b the ventral body region, MBL in $\mathbf{c}$ the ventral body region with substance storage in the basal part of the stratum corneum; DAB visualization, for abbreviations see Fig. 2
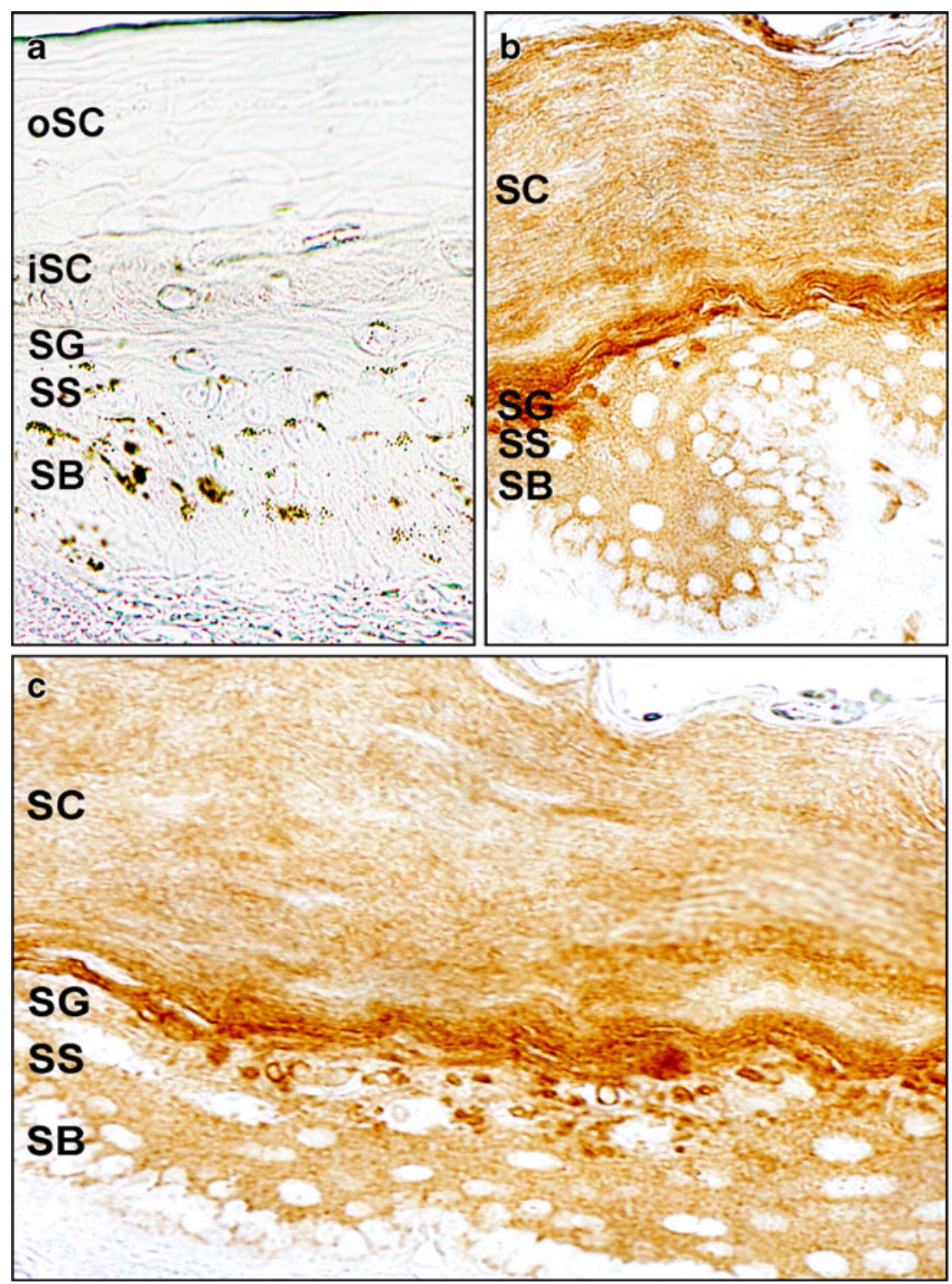

causes the release of antimicrobial peptides, inflammatory cytokines and chemokines, and costimulatory molecules (Tipping 2006).

For the CLRs, there was substantial evidence that collectins and ficolins are predominantly found at the interface of body and environment, i.e., at epidermal (Meyer et al. 2008) and mucosal surfaces (Uemura et al. 2002; Wagner et al. 2003; Holmskov et al. 2003; Van de Wetering et al. 2004; Lillie et al. 2005). Both subgroups have the same recognition capacities for bacteria, for example, MBL recognizes lipopolysaccharides (LPS) and mannan-like high mannose structures and has been shown to interact with a wide variety of Gram-positive bacteria and various types of their cell wall component lipoteichoic acid. Due to the fact that LPS likewise is a major glycolipid component on the outer membrane of Gram-negative bacteria, these are additionally included as ligands for collectins (Lynch et al. 2004; Van de Wetering et al. 2004; Kanazawa 2007). In contrast to Uemura et al. (2002), we consider that MBL is not necessary to maintain sterility at epithelial surfaces, but that a certain "antigenic pressure" is required for the production of this substance. This seems also true for Lficolins that have a wider range of pathogen specificity and interact with Gram-negative and Gram-positive bacteria (Matsushita and Fujita 2002; Kanazawa 2007; Runza et al. 2008). Such ideas would generally corroborate the view of a broad spectrum of bacteria present, in particular, on the surface of the ventral epidermis of the pangolin which is protected by a dense hair coat. Regarding the negative results obtained for dectin-1, it seems that a severe challenge by dermatophytes (Herre et al. 2004; Dennehy and Brown 2007) is not the case in the pangolin.

Secondly, the directly attacking CAPs are found in various epithelial tissues. These broad spectrum antibiotics 
Fig. 5 Immunohistochemical demonstration of cationic antimicrobial peptides in the epidermis of the Malayan pangolin; $\beta$-defensin 2 in a the hinge region of a scale in the dorsolateral body region, $\beta$-defensin 3 in $\mathbf{b}$ the dorsolateral body region showing also a longitudinal section of the bulbus of a hair follicle, and $\mathbf{c}$ the ventral body region; $\mathrm{DAB}$ visualization. $H F$ hair follicle, for the other abbreviations see Fig. 2
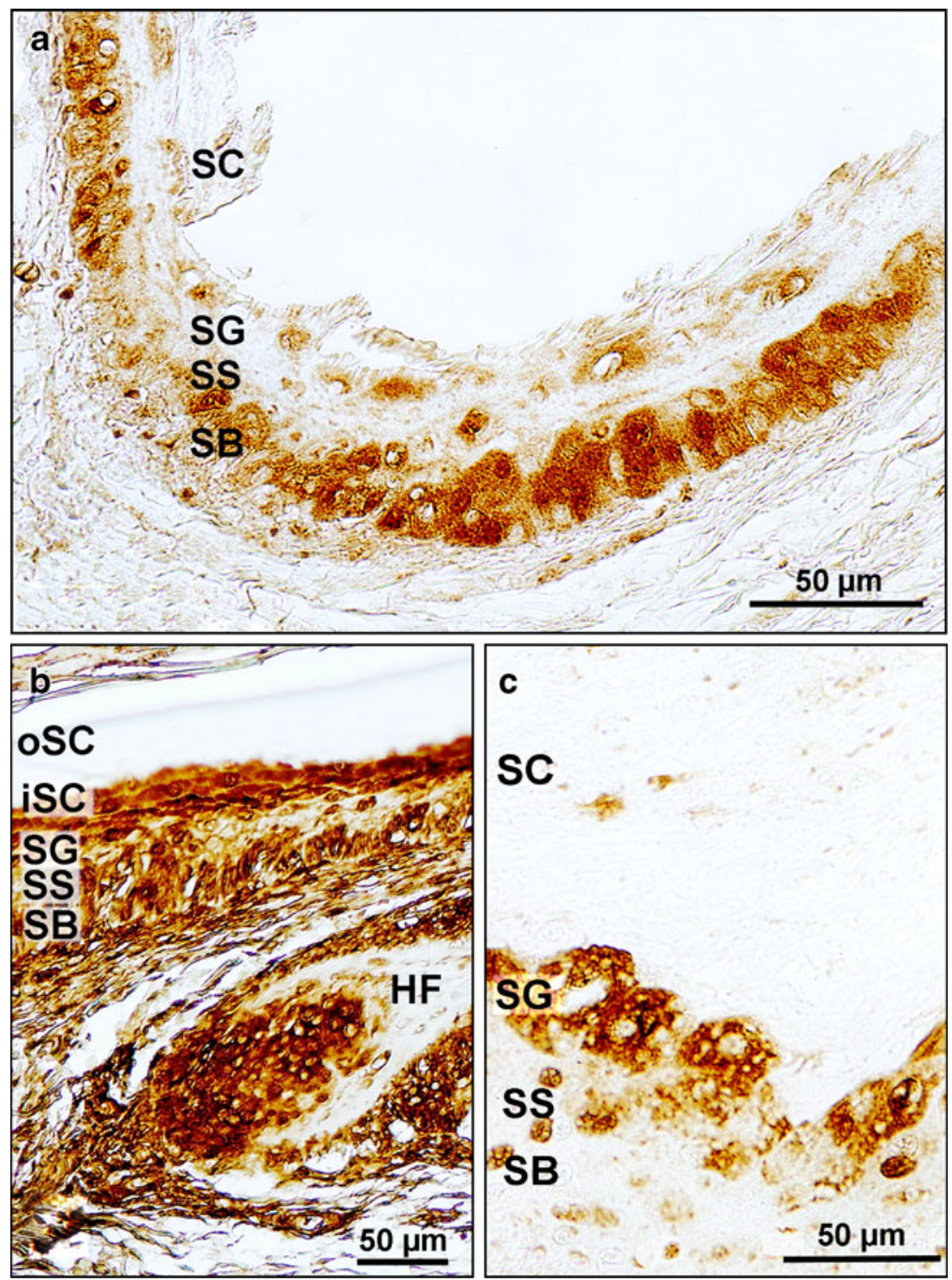

have been demonstrated to kill Gram-positive and Gramnegative bacteria, fungi, mycobacteria, and enveloped viruses, and unlike the majority of conventional antibiotics, they may also have the ability to function as immunomodulators (Dale and Fredericks 2005; Braff and Gallo 2006). Elias and Choi (2005) argued that hBD-2 and -3 and CAT are expressed at low levels in unperturbed skin, but occur in higher levels in healing wounds and in inflammatory dermatoses. Results from the mammalian esophagus epithelium (Hornickel 2009) confirmed the view of the latter authors that these substances are expressed constitutively. Thus, it can be concluded that the production of a diverse repertoire of CAPs is most likely a key factor in allowing the epithelia and their surfaces to maintain homeostasis concerning the diverse colonizing microbiota. Generally, all such substances are perfectly positioned to intercept pathogenic microorganisms when these attempt to penetrate the epidermis in between the corneocytes. Although cathelicidin was the only CAP that could be demonstrated regularly in the dorsolateral and the abdominal body region, it was obvious that all the three specific antimicrobial peptides were generally available in the epidermis and the outer epithelial root sheath of the hair follicles of the pangolin to answer rapidly to possible attacks of noncommensal bacteria and fungi. Multitudes of such microorganisms are found, particularly, in the warm subtropical and tropical regions which are the typical distribution ranges of all members of the family Pangolidae.

Moreover, enzymes participate in the first line of defense targeting microbial structures, whereby lysozyme is the most important member of this substance group. It destroys the peptidoglycans of Gram-positive bacteria by cleaving 
Fig. 6 Immunohistochemical demonstration of cationic antimicrobial peptides and lysozyme in the epidermis of the Malayan pangolin; cathelicidin in $\mathbf{a}$ the dorsolateral and $\mathbf{b}$ the ventral body region, lysozyme in $\mathbf{c}$ the dorsolateral body region and $\mathbf{d}$ the outer epithelial root sheath of a hair follicle (cross section); $\mathrm{DAB}$ visualization. $o E R S$ outer epithelial root sheath, $H$ hair fibre, for the other abbreviations see Fig. 2
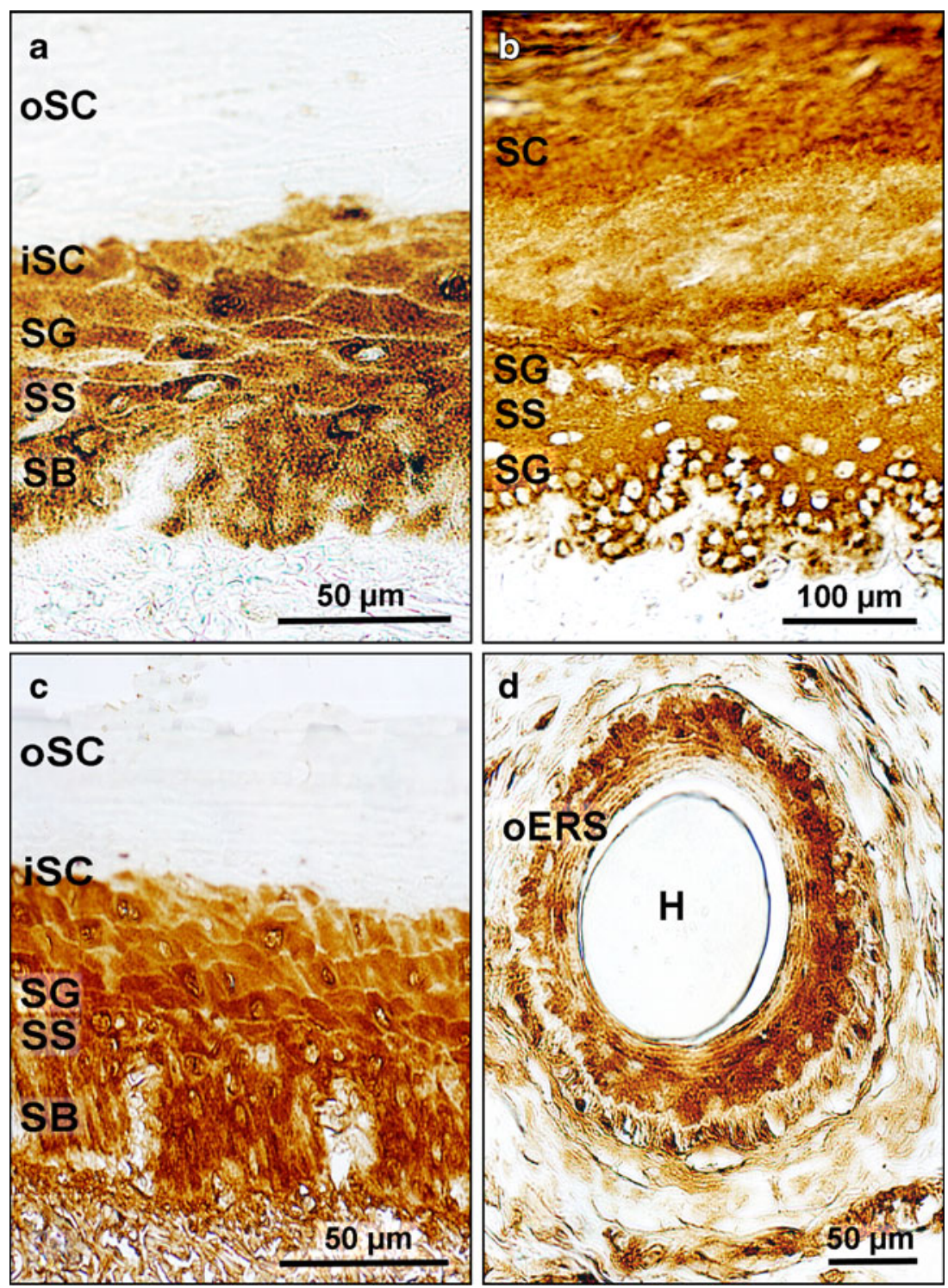

the bond between $\mathrm{N}$-acetyl glucosamine and $\mathrm{N}$-acetyl muraminic acid (Niyonsaba and Ogawa 2005), so that recognition and adhesion of the microorganisms to cells is impeded. Regarding the pangolin skin, strongly positive reactions for lysozyme were especially found in the epidermis of the dorsolateral body region, as indicated by a distinct staining of the stratum granulosum and the inner layer of the stratum corneum. This means that a constant, although low level of lysozyme, is available here below the scale and in its hinge region, as comparable to findings from the mammalian esophagus epithelium (Hornickel 2009). In conclusion, lysozyme forms an innate chemical protection shield that can be activated very rapidly against microbial adhesion and invasion, which may occur particularly in the rather unprotected hinge region of the pangolin scales with its relatively thin epidermis.

\section{Conclusions}

The very specific epidermis of the pangolin (M. javanica) produces all important substances of innate immunity, with a general regional difference. This means that the hard horny scales of the dorsolateral body region offer little possibilities for the adhesion of a commensal or noncommensal microbial flora, in contrast, however, to the epidermis of the ventral body region with its thick and soft stratum corneum protected by a dense and fine hair coat. Thus, epithelial defense is clearly more intensive in the abdomen, also because of the excellent and rather undisturbed biotope conditions for microbiota on the epidermal surface in this region.

Acknowledgments The excellent technical assistance of Marion Gähle and Doris Walter is gratefully acknowledged. 


\section{References}

Bals R, Wang XR, Meegalla RL, Wattler S, Weiner DJ, Nehls MC, Wilson JM (1999) Mouse ß-defensin 3 is an inducible antimicrobial peptide expressed in the epithelia of multiple organs. Infect Immun 67:3542-3547

Bos JD, Pasch MC, Asghar SS (2001) Defensins and complement systems from the perspective of skin immunity and autoimmunity. Clin Dermatol 19:563-572

Braff MH, Gallo RL (2006) Antimicrobial peptides: an essential component of the skin defensive barrier. Curr Topics Microbiol Immunol 306:1-110

Dale BA, Fredericks LP (2005) Antimicrobial peptides in the oral environment: expression and function in health and disease. Curr Issues Mol Biol 7:119-133

Debenedictis C, Joubeh S, Zhang G, Barria M, Ghohestani RF (2001) Immune functions of the skin. Clin Dermatol 19:573-585

Dennehy KM, Brown GD (2007) The role of the B-glucan receptor Dectin-1 in control of fungal infection. J Leukocyte Biol 82:253258

Elias PM, Choi EH (2005) Interactions among stratum corneum defensive functions. Exp Dermatol 14:719-726

Fujita T, Matsushita M, Endo Y (2004) The lectin-complement pathway-its role in innate immunity and evolution. Immunol Revs 198:185-202

García JR, Jaumann F, Schulz S, Krause A, Rodríguez-Jiménez J, Forssmann U, Adermann K, Kluever E, Vogelmeier C, Becker D, Hedrich R, Forssmann WG, Bals R (2001) Identification of a novel, multifunctional $\beta$-defensin (human $\beta$-defensin 3) with specific antimicrobial activity. Its interaction with plasma membranes of Xenopus oocytes and the induction of macrophage chemoattraction. Cell Tissue Res 306:257-264

Harder J, Bartels J, Christophers E, Schroeder JM (2001) Isolation and characterization of human B-defensin-3, a novel human inducible peptide antibiotic. J Biol Chem 276:5707-5713

Hautzer NW, Wittkuhn JF, McCaughey WTE (1980) Trypsin digestion in immunoperoxidase staining. J Histochem Cytochem 28:52-53

Herre J, Willment JA, Gordon S, Brown GD (2004) The role of Dectin-1 in antifungal immunity. Crit Rev Immunol 24:193203

Holmskov U, Thiel S, Jensenius JC (2003) Collectins and ficolins: humoral lectins of the innate immune defense. Annu Rev Immunol 21:547-578

Hornickel I (2009) Investigations on the innate immunity of the esophagus epithelium of domesticated mammals. Diss vet med, Univ Vet Med Hannover

Ishii M, Hashimoto M, Oguma K, Kano R, Moritomo T, Hasegawa A (2006) Molecular cloning and tissue expression of canine Toll-like receptor 2 (TLR2). Vet Immunol Immunopathol 110:87-95

Kaisho T, Akira S (2003) Regulation of dendritic cell function through Toll-like receptors. Curr Mol Med 3:373-385

Kakinuma Y, Endo Y, Takahashi M, Nakata N, Matsushita M (2003) Molecular cloning and characterization of novel ficolins from Xenopus laevis. Immunogenetics 55:29-37

Kanazawa N (2007) Dendritic cell immunoreceptors. C-type lectin receptors for pattern-recognition and signalling on antigenpresenting cells. J Dermatol Sci 45:77-86

Kloos WE, Zimmerman RJ, Smith RF (1976) Preliminary studies on the characterization and distribution of Staphylococcus and Micrococcus species on animal skin. Appl Environm Microbiol 31:53-59

Krogh HV, Christensen S (1977) Beiträge zur Dermatologie von Hund und Katze. Tierärztl Prax 5:389-393
Lillie BN, Brooks AS, Keirstad ND, Hayes MA (2005) Comparative genetics and innate immune functions of collagenous lectins in animals. Vet Immunol Immunopathol 108:97-110

Liumsiricharoen M, Prpong T, Suprasert A, Chungsamarnyart N, Chuntrakru S, Pongchairerk U, Jongmeepornsirisopa P (2006) Anatomy of the Malayan pangolin (Manis javanica). Kasetsart Univ, Bangkok

Linde A, Blecha F, Melgarejo T (2007) Toll-like receptor (TLR) 2 and TLR4 gene expression in canine heart. Amer J Animal Vet Sci 2:6-10

Lynch NJ, Roscher S, Hartung T, Morath S, Matsushita M, Maennel DN, Kuraya M, Fujita T, Schwaeble W (2004) L-ficolin specifically binds to lipoteichoic acid, a cell wall constituent of Gram-positive bacteria, and activates the lectin pathway of complement. J Immunol 172:1198-1202

Matsushita M, Fujita T (2002) The role of ficolins in innate immunity. Immunobiology 205:490-497

Medzhitov R, Janeway CA Jr (1997) Innate immunity: the virtues of a nonclonal system of recognition. Cell 91:295-298

Meyer W (2007) Demonstration of lysozyme and antimicrobial peptides in the temporal gland of the African elephant (Loxodonta africana). Mammal Biol 72:251-255. doi:10.1016/j. mambio.2006.05.003

Meyer W, Seegers U (2004) A preliminary approach to epidermal antimicrobial defense in the Delphinidae. Mar Biol 144:841-844

Meyer W, Bollhorn M, Stede M (2000) Aspects of general antimicrobial properties of skin secretions in the common seal Phoca vitulina. Dis Aquatic Org 41:77-79

Meyer W, Kloepper J, Fleischer L-G (2008) Demonstration of Bglucan receptors in the skin of aquatic mammals - a preliminary report. Eur J Wildlife Res 54:479-486

Meyer W, Neurand K, Tanyolac A (2001) General anti-microbial properties of the integument in fleece producing sheep and goats. Small Ruminant Res 41:181-190

Meyer W, Seegers U, Herrmann J, Schnapper A (2003) Further aspects of the general antimicrobial properties of pinniped skin secretions. Dis Aquatic Org 53:177-179

Mohr E (1961) Schuppentiere (Neue Brehm Buecherei 284). Ziemsen, Wittenberg

Niyonsaba F, Ogawa H (2005) Protective roles of the skin against infection: Implication of naturally occurring human antimicrobial agents [ß]-defensins, cathelicidin LL-37 and lysozyme. J Dermatol Sci 40:157-168

Runza VL, Schwaeble W, Maennel DN (2008) Ficolins: novel pattern recognition molecules of the innate immune response. Immunobiology 213:297-306

Schroeder JM (1999) Epithelial peptide antibiotics. Biochem Pharmacol 57:121-134

Shimada J, Moon SK, Lee HY, Takeshita T, Pan H, Woo JI, Gellibolian R, Yamanaka N, Lim DJ (2008) Lysozyme M deficiency leads to an increased susceptibility to Streptococcus pneumoniae-induced otitis media. BMC Infect Dis 8:134

Short ML, Nickel J, Schmitz A, Renkawitz R (1996) Lysozyme gene expression and regulation. EXS 75:243-257

Spearman RIC (1967) On the nature of the horny scales of the pangolin. J Linn Soc (Zool) 46:267-273

Takahashi M, Iwaki D, Matsushita A, Nakata M, Matsushita M, Endo Y, Fujita T (2006) Cloning and characterization of mannosebinding lectin from lamprey (Agnathans). J Immunol 176:48614868

Taylor PR, Tsoni SV, Willment JA, Denehy KM, Findon H, Haynes K, Steele C, Botto M, Gordon S, Brown GD (2007) Dectin-1 is required for $\beta$-glucan recognition and control of fungal infection. Nat Immunol 8:31-38

Tipping PG (2006) Toll-like receptors: the interface between innate and adaptive immunity. J Amer Soc Nephrol 17:1769-1771 
Tong J, Ren L-Q, Chen B-C (1995) Chemical constitution and abrasive wear behaviour of pangolin scales. J Material Sci Lett 14:1468-1470

Tong J, Lue T-B, Ma Y-H, Wang H-K, Ren L-Q, Arnell RD (2007) Two-body abrasive wear of the surfaces of pangolin scales. J Bionic Engin 4:077-084

Uemura K, Saka M, Nakagawa T, Kawasaki N, Thiel S, Jensenius JC, Kawasaki T (2002) L-MBP is expressed in epithelial cells of mouse small intestine. J Immunol 169:69456950

Van de Wetering JK, Van Golde LMG, Batenburg JJ (2004) Collectinsplayers of the innate immune system. Eur J Biochem 271:12291249

Wagner S, Lynch NJ, Walter W, Schwaeble WJ, Loos M (2003) Differential expression of the murine mannose-binding lectins A and $\mathrm{C}$ in lymphoid and nonlymphoid organs and tissues. $\mathrm{J}$ Immunol 170:1462-1465
Wassef A, Janardhan K, Pearce JW, Singh B (2004) Toll-like receptor 4 in normal and inflamed lungs and other organs of pig, dog and cattle. Histol Histopathol 19:1201-1208

Wilson DE, Reeder DM (eds) (2005) Mammal species of the world, 3rd edn. Johns Hopkins University Press, Baltimore

Yang D, Chertov O, Oppenheim JJ (2001) The role of mammalian antimicrobial peptides and proteins in awakening of innate host defenses and adaptive immunity. Cell Mol Life Sci 58:978-989

Yasui T, Fukui K, Nara T, Habata I, Meyer W, Tsukise A (2007) Immunocytochemical localization of lysozyme and B-defensin in the apocrine glands of the equine scrotum. Arch Dermatol Res 299:393-397

Zanetti M (2005) The role of cathelicidins in the innate host defenses of mammals. Curr Issues Mol Biol 7:179-196

Zhu S, Gao B (2009) A fossil antibacterial peptide gives clues to structural diversity of cathelicidin-derived host defense peptides. FASEB J 23:13-20 